\title{
Growth, Mortality and Exploitation Rates of African Moonfish (Selene dorsalis, Gill 1863) Encountered in the Coast of Ghana (West Africa)
}

\author{
Samuel K. K. Amponsah, Berchie Asiedu, Selasi Yao Avornyo, Seyramsarah Blossom Setufe, \\ Nana Ama Boadu Afranewaa and Pierre Failler
}

\section{ABSTRACT}

\begin{abstract}
Growth, mortality and exploitation rate of Selene dorsalis (Gill, 1863) from the continental shelf of Ghana (West Africa) were examined between July 2018 and June 2019. The study provided results on fishery dynamics parameters needed to estimate the stock status and characteristics of $S$. dorsalis in the coast of Ghana. Monthly length-frequency data were collected from 629 samples and analysed using fisheries models fitted in TropFishR package in $R$ software. The von Bertalanffy growth parameters were utilised to analyse the population dynamics of the species using ELEFAN Simulating Annealing. Based on the estimates, the asymptotic total length $\left(L_{\infty}\right)$ was 22.2 $\mathrm{cm}$, the coefficient of growth $(\mathrm{K})$ was 0.76 year $^{-1}$, and the calculated growth performance index (phi) was 2.58 with $R n$ value of 0.55 . The total mortality rate $(Z)$ was 3.32 year $^{-1}$ with a natural mortality rate $(M)$ of 1.21 year $^{-1}$ and fishing mortality rate $(F)$ of 2.11 year $^{-1}$. The exploitation rate $(E)$ estimated for the species was above the optimum level of 0.5 , which indicates that $S$. dorsalis is overexploited in the coast of Ghana. It can be concluded that the exploitation rate of $S$. dorsalis has exceeded the optimum limit, hence the need for enforcement and improvement of fisheries management measures such as mesh size regulations, capping of canoes, closed fishing seasons and compliance with fisheries policies.
\end{abstract}

Keywords: Ghana, Growth rate, Mortality rates, Population parameters, TropFishR.
Published Online: March9, 2021

ISSN: $2684-5199$

DOI: $10.24018 /$ ejbio.2021.2.2.154

Samuel K. K. Amponsah

Department of Fisheries and Water Resources, University of Energy and Natural Resources, Sunyani, Ghana. Berchie Asiedu *

Department of Fisheries and Water Resources, University of Energy and Natural Resources, Sunyani, Ghana.

(e-mail: berchie.asiedu@ uenr.edu.gh/ berchieasiedu@yahoo.com)

Selasi Yao Avornyo

ESL Consulting, Accra, Ghana.

Seyramsarah Blossom Setufe

Department of Fisheries and Water

Resources, University of Energy and

Natural Resources, Sunyani, Ghana.

Nana Ama Boadu Afranewaa

Department of Fisheries and Water Resources, University of Energy and

Natural Resources, Sunyani, Ghana.

Pierre Failler

Centre for Blue Governance, University of Portsmouth, Richmond Building, Portsmouth, Portland Street, Portsmouth, UK.

*Corresponding Author

\section{INTRODUCTION}

Fish and fisheries make important contributions to food and nutrition security in many countries. However, in many parts of the world, fish stocks are on the decline. This is greatly going to affect the contribution of the seafood industry to achieve the United Nations Sustainable Development Goals. It is thus imperative to give attention to the sustainable management of fish stocks. The population characteristics of fishes are very important inputs in the assessment and management of fish stocks [1]. With world fish stocks currently being inadequately managed resulting in overexploitation and decline [2], there is the need for information on key parameters to help in ensuring adequate management of fisheries. Population dynamics of fishes are determined with the major objective of sustainable management and conservation of fish species [3]. Biological parameters such as population dynamics also allow tests of life-history hypothesis and empirical estimations of important parameters of biological and fishery relevance such as length at first maturity and length at maximum yield per [4], [5].

Despite the importance of the estimation of these parameters to fisheries management, there is little information on these key parameters of the over 300 marine species in Ghana including Selene dorsalis. Belonging to the family Carangidae and the order Perciformes, S. dorsalis also known as the African moonfish is an important commercial fish species native to the Atlantic Ocean [6]. Its distribution is from Portugal to South Africa, including Madeira and Cape Verde [7]. According to [8], out of the twenty-two (22) species of the Carangidae family encountered on the mainland coast of tropical West Africa, S. dorsalis is one of the twelve (12) species of the family, landed in Ghana. It is characterized by a short silverly body, a head with a hump above its eyes, and a steep frontal profile that is slightly concave in front of the eyes and possesses a lower prominent jaw [9]. In Ghana, S. dorsalis is used as food and is often smoked, contributing substantially to the annual per capita fish consumption of $25 \mathrm{~kg}$. It is caught in seines when young, particularly from July to November. It is also caught by ali 
and watsa nets at night, however, when older it may be caught by hooks in deep water [8].

Previous studies on this species include the study on the reproductive biology of the African moonfish, S. dorsalis in the continental shelf of Côte d'Ivoire fishery (West Africa) by [2], the study on community ecology of the metazoan parasites of Atlantic Moonfish, Selene setapinnis (Osteichthyes: Carangidae) from the coastal zone of the state of Rio de Janeiro, Brazil by [10] and the study on some aspects of the biology of $S$. dorsalis from Forcados river estuary, Niger delta, Nigeria by [6].

In Ghana, however, studies on $S$. dorsalis includes the study on species diversity and relative abundance of fisheries resources found in beach seine along the central coast of Ghana by [11] and the study on the investigation on fish catch data and its implication for management of small-scale fisheries of Ghana by [12]. Given the paucity of published information on the population dynamics of $S$. dorsalis and the importance of the fishery in the coastal waters and population of Ghana, the purpose of this study was to estimate the exploitation status of $S$. dorsalis, for which information is required to enhance the sustainable management of $S$. dorsalis in Ghana. On a broader scale, this work will also contribute to the FAO initiative of building a comprehensive global database on fish stocks and their main characteristics [13].

\section{MATERIALS AND METHODS}

\section{A. Study Area}

Five fishing communities in the Greater Accra Region of Ghana were selected for the current study. The selection of the five fish landing sampling sites was based on the level of fishing activity and geographical location. These five fish landing sampling locations were Sakumono, Tema, Nungua, Kpone and Prampram (Fig. 1). The primary livelihood of the majority of the inhabitants in the selected five fish sampling sites is fishing and other activities related to pre-harvesting of fish from the wild. The geographical coordinates of the five fish sampling locations are outlined in Table 1.

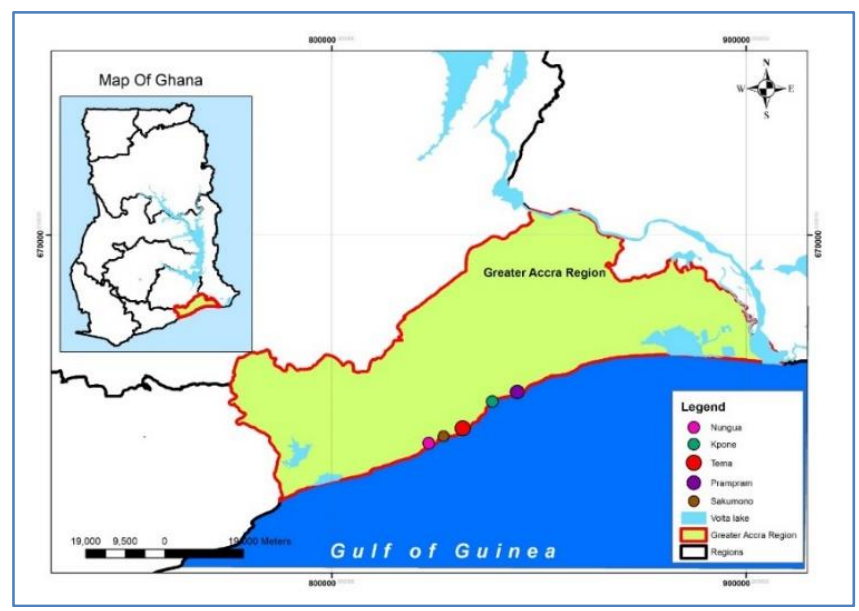

Fig. 1. Map showing the fish landing sampling locations.
TABLE 1: SAMPLING SITES AND THEIR COORDINATES Sampling Locations

Nungua Beach

Tema Canoe Beach

Tema Inshore Fishing

Harbour

Kpone

Prampram

\section{$05^{\circ} 35^{\prime} 42.56^{\prime \prime} \mathrm{N}, 000^{\circ} 04^{\prime} 14.57^{\prime \prime} \mathrm{W}$}

$05^{\circ} 38^{\prime} 39.48^{\prime \prime} \mathrm{N}, 000^{\circ} 00^{\prime} 59.50^{\prime \prime} \mathrm{E}$

$05^{\circ} 38^{\prime} 23.57^{\prime \prime} \mathrm{N}, 000^{\circ} 01^{\prime} 00.38^{\prime \prime} \mathrm{E}$

$05^{\circ} 41^{\prime} 26.84^{\prime \prime} \mathrm{N}, 000^{\circ} 03^{\prime} 52.76^{\prime \prime} \mathrm{E}$ $05^{\circ} 42^{\prime} 17.71^{\prime \prime} \mathrm{N}, 000^{\circ} 06^{\prime} 51.57^{\prime \prime} \mathrm{E}$

\section{B. Data Collection}

Monthly samples were obtained from randomly selected fishermen who apply multifilament fishing gears in their fishing operations. Samples were obtained over a twelve (12) month period (i.e., July 2018 to June 2019), preserved on ice, and transported to the laboratory of the Department of Marine and Fisheries Sciences, University of Ghana for analyses. At the laboratory, identification of the species was done to the lowest level of taxonomy using identification keys by [14]. Measurement of length was performed using a $100 \mathrm{~cm}$ graduated wooden measuring board. In all, 629 specimens of Selene dorsalis were obtained during the study period.

\section{Growth Parameters}

Parameters for the Von Bertalanffy Growth Function (VBGF) including growth rate $(\mathrm{K})$, asymptotic length $(\mathrm{L} \infty)$ and the growth performance index $\left(\Phi^{\prime}\right)$ were estimated using the ELEFAN Simulating Annealing (ELEFAN_SA). Estimation of longevity $\left(\mathrm{T}_{\max }\right)$ for the species followed the formula:

$$
\mathrm{T}_{\max }=3 / \mathrm{K}+\text { to }[15]
$$

The growth performance index was calculated using the formula:

$$
\left(\Phi^{\prime}\right)=2 \log L_{\infty}+\log \mathrm{K}[16]
$$

The theoretical age at length zero $\left(\mathrm{t}_{\mathrm{o}}\right)$ followed the equation:

$\log _{10}\left(-\mathrm{t}_{0}\right)=-0.3922-0.2752 \log _{10} \mathrm{~L}_{\infty}-1.038 \log _{10} \mathrm{~K}[17]$

\section{Mortality Parameters}

Total mortality $(\mathrm{Z})$ was computed using the Linearized length converted catch curve [18]. The natural mortality rate (M) was calculated using the equation:

$$
\mathrm{M}=4.118 \mathrm{~K}^{0.73} \mathrm{~L}^{-0.333}[19]
$$

Fishing mortality (F) was calculated as:

$$
\text { Z-M [20] }
$$

The exploitation rate (E) was computed as:

$$
\mathrm{F} / \mathrm{Z}[21]
$$

\section{E. Length at First Capture $\left(L c_{50}\right)$}

The ascending left part of the length converted catch curve was used in estimating the probability of length at first capture $\left(\mathrm{Lc}_{50}\right)$ in addition to the length at both 75 and 95 
percent capture which correlates with the cumulative probability at $75 \%$ and $95 \%$, respectively [22].

\section{F. Length at First Maturity $\left(\operatorname{Lm}_{50}\right)$}

The length at first maturity $\left(\mathrm{Lm}_{50}\right)$ as:

$$
\mathrm{Lm}_{50}=0.8979 \times \log _{10}(\mathrm{~L} \infty)-0.0782[4]
$$

\section{G. Data Analyses}

The TropFishR package in $\mathrm{R}$ programming [23] was used in assessing the population parameters of specimens of $S$. dorsalis that were encountered during the study period.

\section{RESULTS}

\section{A. Growth Parameters}

Fig. 2 shows the reconstructed length-frequency distribution superimposed with the growth curves. The asymptotic length $(\mathrm{L} \infty)$, growth rate $(\mathrm{K})$ and growth performance index were $22.2 \mathrm{~cm}$ TL, 0.76 year $^{-1}$ and 2.58, respectively with $\mathrm{Rn}$ value of 0.55 (Table 2).

The Von Bertalanffy Growth Function (VBGF) for $S$. dorsalis was:

$$
\mathrm{L}_{\mathrm{t}}=22.2 \times\left(1-\mathrm{e}^{-0.76(\mathrm{t}+0.23)}\right)
$$

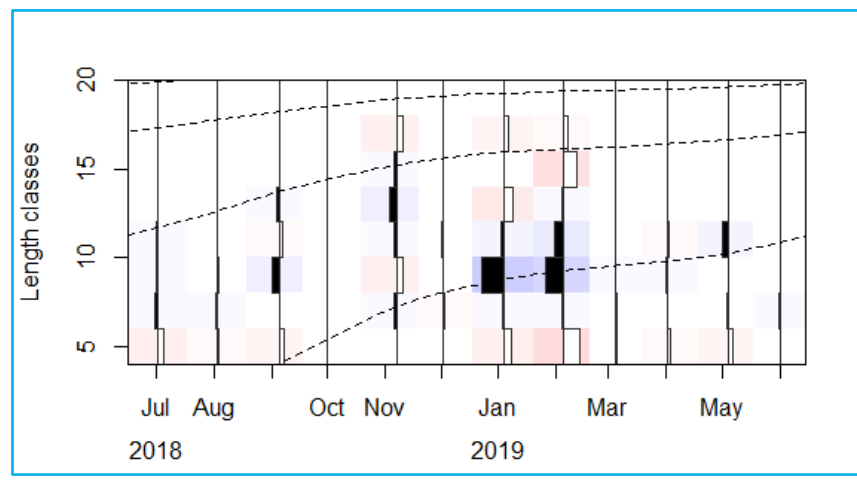

Fig. 2. Reconstructed monthly length-frequency distribution of $S$. dorsalis.

The estimated theoretical age at birth $\left(\mathrm{t}_{\mathrm{o}}\right)$ and longevity for the assessed fish species are presented in Table 2.

\section{B. Length at First Maturity $\left(\mathrm{Lm}_{50}\right)$}

The length at first maturity $\left(\mathrm{Lm}_{50}\right)$ was estimated as $13.5 \mathrm{~cm}$ (Table 2).

\begin{tabular}{|c|c|c|}
\hline Indicators & Unit & Value \\
\hline Growth rate $(\mathrm{K})$ & year $^{-1}$ & 0.76 \\
\hline Asymptotic length $\left(\mathrm{L}_{\infty}\right)$ & $\mathrm{cm} \mathrm{TL}$ & 22.2 \\
\hline Age at birth $\left(\mathrm{t}_{\mathrm{o}}\right)$ & Years & -0.23 \\
\hline Longevity $\left(\mathrm{t}_{\max }\right)$ & Years & 3.72 \\
\hline Growth performance index(phi) & & 2.58 \\
\hline Response surface $(\mathrm{Rn})$ & & 0.55 \\
\hline Length at first maturity $\left(\mathrm{Lm}_{50}\right)$ & $\mathrm{cm} \mathrm{TL}$ & 13.5 \\
\hline Natural mortality rate (M) & year $^{-1}$ & 1.21 \\
\hline Total mortality rate $(\mathrm{Z})$ & year $^{-1}$ & 3.32 \\
\hline Fishing mortality rate $(\mathrm{F})$ & year $^{-1}$ & 2.11 \\
\hline Exploitation rate $(\mathrm{E})$ & - & 0.63 \\
\hline Length at first capture $\left(\mathrm{Lc}_{50}\right)$ & $\mathrm{cm} \mathrm{TL}$ & 7.61 \\
\hline Critical length at capture (Lc) & - & 0.34 \\
\hline $\mathrm{M} / \mathrm{K}$ & - & 1.60 \\
\hline Number of data points $(\mathrm{N})$ & & 629 \\
\hline
\end{tabular}

TABLE 2: ESTIMATED POPULATION PARAMETERS OF S. DORSALIS FROM

\section{Mortality Parameters}

From the length converted catch curve (Figure 3), the total mortality rate (Z) estimated for $S$. dorsalis was 3.32 year $^{-1}$. The natural mortality rate $(\mathrm{M})$ was $1.21 \mathrm{year}^{-1}$. The fishing mortality rate $(\mathrm{F})$ was 2.11 year $^{-1}$ whiles the exploitation rate (E) recorded was 0.63 .

\section{Probability of Capture}

The length-at-first capture $\left(\mathrm{Lc}_{50}\right)$ was $7.6 \mathrm{~cm}$. Fig. 3 shows the corresponding age for length at first capture.

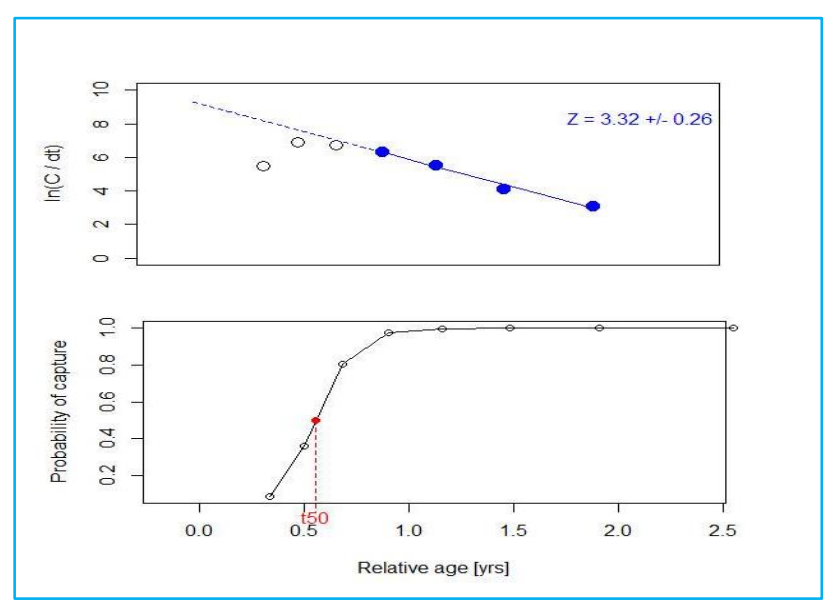

Fig. 3. Length converted catch for Total mortality and probability of capture for $S$. dorsalis.

\section{DISCUSSION}

The growth rate estimated for this study $\left(0.76\right.$ year $\left.^{-1}\right)$ was higher than recorded for other related species like Selene setapinnis $\left(0.49\right.$ year $\left.^{-1}\right)$ [24] but lower than the growth estimate for Selene peruviana $\left(0.95\right.$ year $\left.^{-1}\right)$ [25]. The growth rate $(k)$ from the current study signifies that $S$. dorsalis in Ghana's coastal waters exhibited a fast growth rate, evinced by the low longevity of 3.72 years (Table 2). The estimated fast growth rate of $S$. dorsalis in this study compared to the other related species may be as a result of disparity in ecological characteristics such as habitat, fish adaptive life pattern and location, environmental conditions as a result of regional differences, food abundance or size composition of the stock that directly affect growth rate [15], [21], [20].

The asymptotic length of $S$. dorsalis $(22.2 \mathrm{~cm}$ TL) varied compared to other related species like Selene setapinnis (36.84 cm TL) [24] and Selene peruviana (21 cm TL) [25]. According to [26], growth parameters are very sensitive to samples as such, larger individuals tend to increase the asymptotic length as growth rate decreases, hence, individual size ranges play a key role in estimating the asymptotic length. The variations in estimates of asymptotic lengths may therefore be as a result of the maximum observed length, sampling methods, computation methods used and the obtained length-frequency [18], [27]. The alteration in growth parameters may be associated with climate type, latitudinal differences, and ecological characteristics such as habitat, fish adaptive life pattern and location that directly affect the growth rate [28], [20].

The critical length at capture (Lc) from the study indicated that fishermen in Ghana are harvesting more juveniles of the fish because the calculated Lc was lower than 0.5 [29]. The 
indulgence in such practices over long periods could result in growth overfishing and consequentially, may render recruitment dysfunctional in the future, thereby, leading to a possible collapse and ultimately food insecurity. Furthermore, the length at which this species becomes vulnerable to the fishing gears used by Ghanaian fishermen was lower than the length at first maturity. This implies that the species does not get the opportunity to spawn, at least once, before it is captured. This could negatively impact the recruitment potential of the stocks in the future [30]. There is, therefore, the need to enforce length at ninety-five percent $(95$ $\%)$ capture which is feasible when the mesh size is increased.

According to [31], the consistency of the estimated natural mortality rates $(M)$ was ascertained using the $M / K$ ratio, which has been reported to be within the range of 1.12 and 2.5 for most fishes. The $M / K$ ratio in this study (i.e., 1.60) fell within the acceptable demarcated range. Adaptations to local conditions and exploitation levels may have caused the variations observed in the fishing mortality rate as compared to other studies carried out on other related species [32]. From the present study, the natural mortality rate $\left(1.21 \mathrm{year}^{-1}\right)$ was lower than the fishing mortality rate $\left(2.11\right.$ year $\left.^{-1}\right)$ unlike the related species Selene setapinnis which had its natural mortality rate $\left(0.94\right.$ year $\left.^{-1}\right)$ higher than the fishing rate $(0.28$ year-1 $^{-1}$ [24]. This suggests that unlike Selene setapinnis, the $S$. dorsalis species in the coastal waters of Ghana are more prone to fishing gears than naturally induced mortality situations caused by age, predation, lack of food, spawning stress, diseases, and pollution [27]. The relatively higher fishing mortality rate than the natural mortality rate indicates an imbalanced stock position [33]. This observation reveals derailment from the optimum exploitation rate of 0.5 [34].

The exploitation rate of $S$. dorsalis (0.63) was higher than that of the related species Selene setapinnis (0.23) [24]. This observation suggests that $S$. dorsalis stocks are slightly overexploited because the exploitation rate of the species surpasses the optimum level of 0.5 [34]. The assessed species is known to inhabit the 30-metre zone; as such increasing its vulnerability to the fishing gears of the over 100000 artisanal fishermen in Ghana. This observation may have accounted for the high exploitation rate estimated for the species. This calls for urgent management of the stock through measures including but not limited to reductions in fishing efforts, closed fishing seasons, capping of canoes and creation of marine protected areas (MPAs), to help sustain the stock.

\section{CONCLUSION}

From the study, S. dorsalis encountered in Ghana's coastal waters is a fast growing species and an immature species under high fishing pressure. The species appears to be overexploited in Ghana's marine waters, hence the need to safeguard the stock through proper management measures. Such management measures may include but not be limited to mesh size regulations, closed fishing seasons, capping of canoes and compliance to fisheries policies.

\section{ACKNOWLEDGMENT}

Our appreciation goes to the fishermen who assisted us with data collection during the study period.

\section{REFERENCES}

[1] Tsikliras, A. C., Stergiou, K.I. and Froese, R. (2013). Editorial note on reproductive biology of Fishes. Acta Icthyologica et Piscatoria, 43(1):1-5.

[2] Arra S., Sylla S., Kouame A. C., Zan-BI T. T. and Ouattaraw M. 2018. Reproductive biology of the African moonfish, Selene dorsalis (Gill, 1862) (Carangidae) in continental shelf of Côte d'Ivoire fishery (West Africa). International Journal of Fisheries and Aquatic Studies, 6(2): 358-363.

[3] Arra, S., Sylla, S., Zan-Bi, T. T., Loukou, A. and Ouattara, M. (2020) Stock assessment and population dynamics of Senegal Jack, Caranx senegallus Cuvier, 1833, from industrial fishery of Cote d'Ivoire (West Africa). Agronomie Africaine, 32:37-49.

[4] Froese, R. and Binohlan, C. (2000). Empirical relationships to estimate asymptotic length, length at first maturity and length at maximum yield per recruit in fishes, with a simple method to evaluate length frequency data. Journal of Fish Biology, 56 (4): 758-773.

[5] Garcia, C. B. and Duarte, L. O. (2006). Length-based estimates of growth parameters and mortality rates of fish populations of the Caribbean Sea. Journal of Applied Ichthyology, 22:193-200.

[6] Ogidiaka, E., Atadiose, J., Bekederemo, B. and Omoariagbin, B. (2019). Some aspects of Biology of Selene dorsalis from Forcados river estuary, Niger delta, Nigeria. Journal of Fisheries and Life Sciences, 4(2): 15-16.

[7] Froese, R. and D. Pauly (Eds). (2020). FishBase World Wide Web electronic publication. Retrieved from www.fishbase.org, on 21/1/21.

[8] Edwards, A. J., Gill, C. A and Abohwekyere, P. O. (2001). A Revision of Irvine's Marine Fishes of Tropical West Africa. Darwin Initiative Report 2, Ref. 162/7/451:157 p. .186 pp.

[9] Smith-Vaniz, W.F. (1986). Carangidae. p. 815-844. In P.J.P. Whitehead, M.-L. Bauchot, J.-C. Hureau, J. Nielsen and E. Tortonese (eds.) Fishes of the north-eastern Atlantic and the Mediterranean. UNESCO, Paris. vol. 2. (Ref. 4233).

[10] Cordeiro A. S. and Luque J. L. 2004. Community ecology of the metazoan parasites of Atlantic Moonfish, Selene setapinnis (Osteichthyes: Carangidae) from the coastal zone of the state of Rio de Janeiro, Brazil. Brazilian Journal of Biology, 64(3a): 399-406.

[11] Aggrey-Fynn, J. and Sackey-Mensah, R. (2012). Species Diversity and Relative Abundance of Fisheries Resources Found in Beach Seine along the Central Coast of Ghana. West African Journal of Applied Ecology, 20(1): 9pp

[12] Nunoo, F. K. E. and Berchie, A. (2013). An investigation of fish-catch data and its implications for management of small-scale fisheries of Ghana. International Journal of Fisheries and Aquatic Sciences, 2(3): 46-57.

[13] FAO. (2021). Capture fisheries resources. Rome, FAO. http://www.fao.org/fishery/resources/capture/en (accessed on December 02, 2020).

[14] Schneider, W. (1990). FAO species identification sheets for fishery purposes. Field guide to the commercial marine resources of the Gulf of Guinea. Prepared and published with the support of the FAO Regional Office for Africa. Rome: FAO, 268 p.

[15] Anato, C. B. (1999) Les Sparidae des côtes béninoises: Milieu de vie pêche, présentation des espèces et biologie de Dentex angolensis Poll et Maul, 1953. Thèse de Doctorat d'Etat es Sciences, Fac. Sci. 1060 Tunis, $277 \mathrm{p}$

[16] Munro, J. L. and Pauly, D. (1984). Once more on the comparison of growth in fish and invertebrates. ICLARM Fishbyte, 2: $21 \mathrm{p}$.

[17] Aleev, Y. G. (1952). Horse Mackerel of the Black Sea, VNIRO Press.

[18] Sparre, P. and Venema, S.C. (1992) Introduction to Tropical Fish Stock Assessment. Part 1. Manual, FAO Fisheries Technical Paper, 306. No. 1, Review 1, FAO, Rome, 376 p.

[19] Then, A. Y., Hoenig, J. M, Hall, N. G. and Hewitt D. A. (2015) Evaluating the predictive performance of empirical estimators of natural mortality rate using information on over 200 fish species. ICES Journal of Marine Science. 72: 82-92.

[20] Qamar, N, Panhwar, S. K. and Brouwer, S. (2016). Population Characteristics and Biological Reference Point Estimates for Two Carangid Fishes, Megalaspis cordyla and Scomberoides tol, in the Northern Arabian Sea Coast of Pakistan. Pakistan Journal of Zoology, 48(3): 869-874. 
[21] Georgiev, Z. M. and Kolarov, P. (1962). "On the migration and distribution of horse mackerel (Trachurus ponticus Aleev) in the western part of Black Sea," Arbeiten des Zentralen Forschungsinstitutes Fur Fishzught und Fisherei Varna, 2: 148-172.

[22] Pauly, D. (1984). Fish population dynamics in tropical waters: a manual for use with programmable calculators. ICLARM Contribution, Makati, Metro, Manila, Philippines, (143): 325.

[23] Taylor, M. and Mildenberger, T. K. (2017). Extending electronic length frequency analysis in R. Fisheries Management and Ecology. s24: 330-338.

[24] Costa, Marcus Rodrigues da, Tubino, Rafael de Almeida, \& MonteiroNeto, Cassiano. (2018). Length-based estimates of growth parameters and mortality rates of fish populations from a coastal zone in the Southeastern Brazil. Zoologia (Curitiba), 35, e22235. https://doi.org/10.3897/zoologia.35.e22235.

[25] Morales-Nin, B. (1994). Growth of demersal fish species of the Mexican Pacific Ocean. Marine Biology, 121: 211-217.

[26] Espino Barr, E., Gallardo Cabello, M., Cabral Solís, E. G., Garcia Boa, A. and Puente Gómez, M. (2008). Growth of the Pacific jack Caranx caninus (Pisces: Carangidae) from the coast of Colima, México. Revista de Biologia Tropical, 56 (1): 171-179.

[27] Amponsah S. K. K., Ofori-Danson P. K., Nunoo F. K. E. (2016). Study of the population parameters of the bigeye grunt, Brachydeuterus auritus (Valenciennes, 1831) in Ghanaian coastal waters and its implications for management. International Journal of Fisheries and Aquatic Studies, 4 (6): 413-419.

[28] Tarkan, A. S. and Vilizzi, L. (2015). Patterns, latitudinal clines and countergradient variation in the growth of roach Rutilus rutilus (Cyprinidae) in its Eurasian area of distribution. Reviews in Fish Biology and Fisheries, 25 (4): 587-602. DOI: .https://doi.org/10.1007/s11160-015-9398-6.

[29] Pauly, D. and Soriano, M. L. (1986). Some practical extentions to Beverton and Holt's relative yield per- recruit model, pl49-495. In J.L.Maclean, L.B.Dizon and L.V.Hosillos (eds) First Asian Fisheries Forum, Asian Fisheries Society, Manila, Philippines.

[30] Gheshlaghi, P., Vahabnezhad, A. and Taghavi Motlagh, S. A. (2012). Growth parameters, mortality rates, yield per recruit, biomass, and MSY of Rutilus frisii kutum, using length frequency analysis in the Southern parts of the Caspian Sea. Iranian Journal of Fisheries Science, 11(1):48-62.

[31] Macer, C. T. (1977). "Some aspects of the biology of the horse mackerel [Trachurus trachurus (L.)] in waters around Britain," Journal of Fish Biology, 10(1): 51-62.

[32] De Queiroz, J. D. G. R., Salvador, N. L. A., Sousa, M. F., Da Silva, V. E. L., Fabré, N. N., Vandick S. and Batista, V. S. (2018). Life-History Traits of Chloroscombrus Chrysurus (Actinopterygii: Perciformes: Carangidae) In Tropical Waters of The Atlantic Ocean. Acta Ichthyologica Et Piscatoria, 48 (1): 1-8.

[33] Azim M. K. M., Amin S. M. N., Romano N., Arshad A. and Yusoff F. M. (2017). Population Dynamics of Yellowtail Scad, Atule mate (Cuvier 1833) in Marudu Bay, Sabah, Malaysia; Sains Malaysiana, 46(12): 2263- 2271.

[34] Gulland, J. A. (1971). The fish resources of the oceans. West by fleet survey. Fishing News (Books) Ltd., for FAO, West By fleet, England:255. 